\title{
Influence of Transformational Leadership and Public Service Motivation on Job Performance of Nurses in Thailand
}

\author{
Kanon Trichandhara ${ }^{1}$, Ratana Somrongthong ${ }^{1}$, \& Idsaratt Rinthaisong ${ }^{2}$ \\ ${ }^{1}$ College of Public Health Sciences, Chulalongkorn University, Bangkok, Thailand \\ ${ }^{2}$ Faculty of Management Sciences, Prince of Songkla University, Songkhla, Thailand \\ Correspondence: Ratana Somrongthong, College of Public Health Sciences, Chulalongkorn University, Bangkok, \\ Thailand. Tel: 66-81-692-8582. E-mail: Ratana.So.chula.ac.th
}

\author{
Received: May 2, 2019 \\ Accepted: May 11, 2019 \\ Online Published: May 31, 2019 \\ doi:10.5539/ass.v15n6p59 \\ URL: https://doi.org/10.5539/ass.v15n6p59
}

\begin{abstract}
Leaders' role is significant in motivating employee performance. The present study examines the influence of transformational leadership and public service motivation (PSM) on task performance of nurses in three southernmost provinces in Thailand. Based on the data collected from 813 nurses in public hospitals, the results showed that the proposed model was well-fitted to the empirical data. The results of the study indicated that transformational leadership and public service motivation had effects directly on both task performance and contextual performance. Furthermore, transformational leadership had indirect effects on task performance and contextual performance through public service motivation. These findings suggest that nurses' job performance could be enhanced by the motivational influence of their immediate leaders.
\end{abstract}

Keywords: task performance, contextual performance, transformational leadership, public service motivation

\section{Introduction}

The unrest in the three Southern border provinces of Thailand has continued to be an important problem for the country, which has immeasurably affected the area in terms of life and property, mental health, culture and the way of life. Among the most frequently mentioned causes of the unrest are the deteriorating relationship and the lack of trust between the government officials and the local people. Thus, government officials could be an important factor to drive the mechanism in the bureaucracy or the governmental system for solving the problem in the three Southern border provinces.

Studies in management sciences have found that organizations give much importance to their personnel because they are considered as human capital. Indeed, employees constitute an important foundation of work and thus personnel management can have effects on organizational security in the long run. In the future, the changing social, economic, political and cultural conditions, and technology advancements will change work conditions and work characteristics and, thus, personnel will need more work skills, knowledge, ability and learning to meet the needs of organizations. Organizations attach more importance to employees' behavior because they come from different backgrounds to work together for their organizations to meet both organizational and personal goals. Therefore, employees' behavior is an important factor that promotes their organizational performance (Motowidlo, Borman, \& Schmidt, 1997). Thus, it is argued that if the job performance of public personnel is recognized and accepted by people in the three Southern border provinces, violence resulted from the unrest in the area should be reduced to some extent.

The aim of this study is on nurses who play a vital role in delivering high quality, patient-centered care that is related to healthcare system's effectiveness (Alliance for Health Reform, 2007). Therefore, it is necessary for them to have behavior for job performance which is key to organizational success (Rahman, 2014), especially to facilitate public health work for people in the Southern border provinces so that they have highest satisfaction which is the main target of government administration.

To date, industrial psychologists and organizations have attempted to examine factors affecting employee job performance. Transformational leadership, where leader behaviors can stimulate subordinates to a higher level of thinking (Bass, 1985; Burns, 1978), is an approach well-accepted for providing understanding of leader effectiveness. Task performance and organizational citizenship behavior (OCB) have been known to be resulted 
from transformational leadership (Fuller, Patterson, Hester, \& Stringer, 1996; Judge \& Piccolo, 2004). Nevertheless, the mechanisms which affect the outcomes of transformational leadership are still necessary such as trust in the employer satisfaction, personal identification, and perceived fairness (Kark et al., 2003; Pillai, Schreisheim, \& Williams, 1999) self-efficacy or group potency (Bono \& Judge, 2003; Shamir, House, \& Arthur, 1993).

The present research draws attention to the role of public service motivation (PSM), which refers to a person's orientation to do good for the society at large (Perry, 2000). Specifically, it is argued here that transformational leaders could help to enhance the effect of PSM and this in turn could lead to higher levels of job performance among employees. According to self-determination theory (SDT), the satisfaction of the needs for autonomy, competence and relatedness, which are the three basic psychological needs, will result in high levels of motivation derived from within individuals or intrinsic motivation and the internalization of external values leading to positive work-related performance (Gagne' \& Deci, 2005). According to Vandenabeele, 2007; Park and Rainey, 2008, public service motivation (PSM) is a self-directed motive, and as found by various studies (Cerase \& Farinella, 2009; Leisink \& Steijn, 2009; Vandenabeele, 2009; Taylor \& Westover, 2011; Kim, 2012), there is association between public service motivation and work-related results such as citizenship behaviors. As further studies are still needed to explore further the mechanisms through which public service motivation (PSM) can affect employee outcomes, this present study will further investigate especially PSM mediating variables.

The present study aimed to explore the effects of transformational leadership, PSM on task performance and contextual performance of nurses in the southernmost provinces of Thailand. Thus, it has contributed to the literature on this matter, and it has also introduced self-determination theory (SDT) to show how task performance and contextual performance, which are employee outcomes, are related to transformational leadership. However, organizational influence which is one of the antecedents of PSM has been examined by only a few studies (Perry \& Vandenabeele, 2008; Gould-Williams et al., 2013). The hypothesized conceptual model is illustrated in Figure 1.

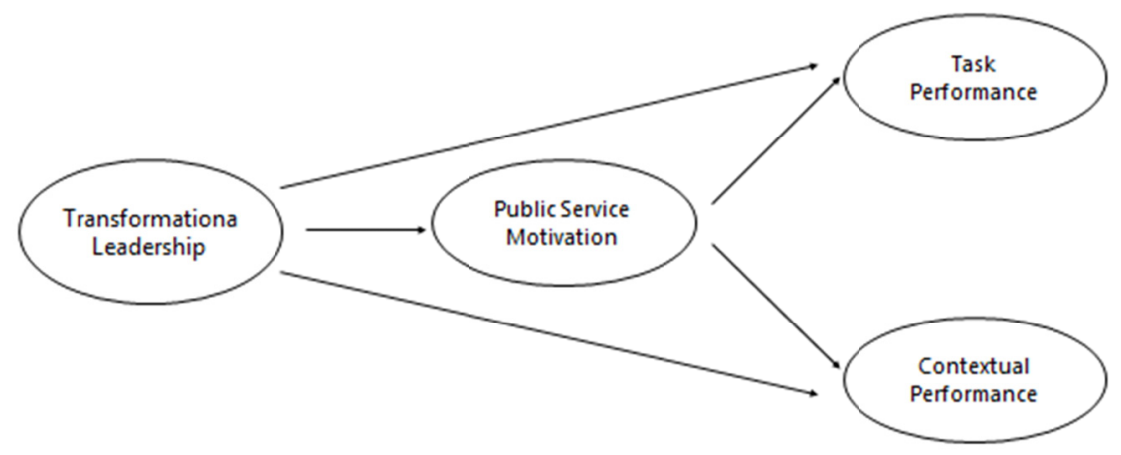

Figure 1. The Hypothesized Theoretical Model

\section{Literature Review and Hypotheses}

\subsection{Job Performance}

Academics have given various definitions to job performance which can be classified into three groups. The first group of academics such as Campbell (1990) places emphasis on behaviors or actions of persons while the second group such as Bernardin and Beatty (1984) places emphasis on outcomes, and the third group places emphasis on both behaviors or actions and outcomes. According to academics, behaviors can be classified into two categories: in-role behaviors and extra-role behaviors. Borman and Motowidlo's (1993) theory of job performance is one of the theories that describes performance domains more accurately. The theory proposed a two-dimension theory of job performance. That is, task performance or in-role behaviors; and contextual performance or extra-role behaviors (Borman \& Motowidlo, 1993). In-role behavior refers to behavior required by the organization in accordance with the responsibilities assigned to employees or as they must do for returns from the organization while extra-role behavior refers to behavior that individuals engage in voluntarily in addition to the responsibilities required by the organization without expecting monetary returns from the organization. These behaviors are instrumental for the organizational effectiveness. 
In nursing, based on the two-dimension theory domains (task performance and contextual job performance) of Bowman and Motowidlo (1993), Greenslade (2008) proposed six aspects of job performance: three aspects of task performance and three aspects of contextual performance. The task performance aspects are: (1) social support, referring to the behaviors nurses perform to meet the emotional needs of patients; (2) information provision, referring to the behaviors nurses provide when giving information and educating the patients and families about the patient's condition and treatment; and (3) technical care, referring to the behaviors nurses perform towards meeting the physical needs of patients by serving and helping patients to address their needs and interests. The three contextual performance aspects are: (1) interpersonal support, defined as the behaviors that support the organization through interpersonal communication including assisting and cooperating with co-workers; (2) job support emphasizing the behaviors that are not required by the organization, demonstration of dedication and persistence, and utmost job performance; and (3) organizational support defined as behaviors where nurses demonstrate commitment to the organization by complying with rules and regulations of the organization as well as allegiance, loyalty, and commitment to organizational objectives (Greenslade, 2008).

\subsection{Transformational Leadership and Job Performance}

Transformational leadership theory is based on Burns' concept (1978) stating that the leader who realizes his subordinates' needs, searches incentives for them and encourages them to be aware of their own needs and such a leader tries to meet subordinates' needs even more. This corresponds with the meaning given by Bass (1985) who defines transformational leader as the leader who tries to encourage and motivate his subordinates to work for the organization to achieve its goal. At the same time, the leader tries to make his subordinates realize the importance of the group's objectives and points out their benefits through those of the organization or the group.

Studies found that the leader who possesses transformational leadership is diligent, works hard, and has outstanding job performance and organizational commitment. Thus, transformational leadership or transactional leadership is considered suitable for this present changing world (Bass, 1985). Transformational leadership is accomplished through four interrelated components: 1) Idealized influence, 2) Inspirational motivation, 3) Intellectual stimulation, and 4) Individualized consideration (Bass, 1985; Burns, 1978). Piccolo and Colquitt (2006) concluded that positive job behaviors and transformational leadership are related. Transformational leadership predicts job performance of public employee performance (Bass \& Riggio, 2006; Paarlberg, Park, \& Rainey, 2008; Trottier, Van Wart, \& Wang, 2008; Wright, Moynihan, \& Pandey, 2012) that helps improve organizational functioning (Smith, Organ, \& Near, 1983). Studies also found that transformational leadership influences good organizational citizenship behavior (Boerner, Eisenbeiss, \& Griesser, 2007; Piccolo \& Colquitt, 2006) and correlations that are strongly consistent with task performance (Judge \& Piccolo, 2004; Piccolo \& Colquitt, 2006). Based on the above reasoning and past empirical evidence, the present study hypothesizes that;

Hypothesis 1: Transformational leadership is positively related to task performance.

Hypothesis 2: Transformational leadership is positively related to contextual Performance.

\subsection{Transformational Leadership and Public Service Motivation (PSM)}

The present research argues that transformational leadership has indirect effect and influence on employees' motivation. Specifically, it focuses on PSM, which is a desire to serve the public or to do good for other people in society or the community (Kjeldsen \& Jacobsen, 2013, p. 901). There are four dimensions to PSM: 1) Attraction to public service is when individuals extremely desire to participate in making public policy which increases their self-esteem. Kelman (1987) specifies that participating in forming public policy is one way individuals who desire to serve the public can do. 2) Compassion or "Patriotism of benevolence" - in this context it is defined by Frederickson and Hart (1985) as loving people who have the same political ideologies as ours and we must protect their rights. 3) Commitment to public values means an individual's wish to do good for the public and is basically altruistic even when it is associated with an individual's opinion (Downs, 1967). 4) Self-sacrifice means an individual's willingness to sacrifice oneself and do good for others for personal rewards (Perry, 1996).

Perry and Wise, 1990 state that people who have higher levels of PSM are not very likely to be dependent on extrinsic rewards to perform their job effectively. According to self-determination theory (SDT), individuals who are motivated are not the only group of people who have PSM. Some individuals may adopt organizational values through effective management and become motivated to serve the public. PSM theory states that people can be convinced by work-related policy to have public-mindedness and desire to serve the public (Perry, 2000; Moynihan \& Pandey, 2007a). Therefore, as a result of the organization's policies, employees may become individuals who have public service motivation (PSM). 
So far, studies have been conducted to find out the effects of transformational leadership on public service motivation (PSM). It has been found by Judge and Piccolo (2004) that transformational leadership had positive effects on fellow co-workers' motivation as also found by Piccolo and Colquitt (2006). Leaders' behaviors were found to be positively related to PSM by Ritz (2009) especially in relation to desire to participate in public policy making as well as devotion to public interest. While Park and Rainey (2008) found transformational leadership and PSM associated with employees' performance, Paarlberg and Lavigna (2010) suggested that transformative leadership is associated with person-organization fit, socialization, work environment, goal-setting theory and self-determination theory with public service motivation.

Based on the above empirical evidence, it is proposed that transformational leadership can satisfy individuals with the three basic psychological needs leading to higher levels of self-motivation. That is, the present study views transformational leadership as an antecedent of PSM. Thus, it is hypothesized that:

Hypothesis 3: Transformational leadership is positively related to public service motivation.

\subsection{The Mediating Role of Public Service Motivation (PSM)}

Self-determination theory (SDT) proposes that, fulfillment of the three basic psychological needs which are needs for autonomy, competence, and relatedness within the organization will lead to intrinsic motivation and the internalization of external values that will result in positive job-related results such as positive performance, good attitudes and improved behaviors, and self-adjustment as well as well-being (Gagne' \& Deci, 2005). As mentioned above, transformational leadership can help satisfy the employee's basic psychological needs within the organization. Hence, motivating employees to display ability and motivation and providing them with opportunity to participate are likely to fulfill the needs for their basic psychological needs, which would result in positive employee outcomes.

This study employs the principles of the theory which state that it is possible to predict the effects of transformational leadership on employee performance. Based on the basis of self-determination theory, this study hypothesizes that:

Hypothesis 4: Transformational leadership is positively related to task performance through public service motivation.

Hypothesis 5: Transformational leadership is positively related to contextual performance through public service motivation.

\subsection{Public Service Motivation (PSM) and Job Performance}

As Brewer (2008) and Houston (2006) mentioned that academics and practitioners are interested in investigating PSM in relation to behavioral and other performance related outcomes. Among the first to investigate the association between PSM and job performance were Perry and Wise (1990) who found that they are related and likewise other studies revealed that PSM is linked to job performance (Grant, 2007; Hondeghem \& Perry, 2009; Kim, 2005; Vandenabeele, 2009), Hence, it is hypothesized that:

Hypothesis 6: Public service motivation is positively related to task performance.

Hypothesis 7: Public service motivation is positively related to contextual performance.

\section{Methodology}

\subsection{Sample and Data Collection}

The sample of this present research was collected from the nurses working in public hospital in the three Southern border provinces: Yala, Pattani, and Narathiwat. The nurses who qualify as respondents for this present research are required to have worked for at least one year in their respective hospitals. The lead author sent out 1,100 survey questionnaires to the nurses and 813 completed surveys were returned, resulting in a response rate of 73.9 percent. As shown in Table 1, the majority of the respondents were female (94.9\%) and are aboit 31 to 40 years old (43.5\%). Most are also married (62.4\%) with a bachelor's degree (92.6\%) and a tenure of less than 10 years (42.5\%). Almost all are registered nurses (99.0\%). and work in community hospitals (48.2\%) in Narathiwat province $(40.5 \%)$.

\subsection{Measurements}

Most of the items used in the survey were developed based on concepts and theories related to measuring variables in models. The measures were rated based on a five-point Likert scale ( 1 as a strongly disagree to 5 as strongly agree) for transformational leadership and public service motivation and seven-point Likert scale $(1=$ not at all to $7=$ a great deal) for job performance. The details of each variable are as follows. 
Transformational leadership (TL) used 20 items that were developed based on Avolio (1999), Bass \& Avolio, 1995, Tejeda, Scandura, \& Pillai (2001), Hinkin \& Schriesheim (2008). Items 1-8 measure idealized influence (TL1); item 5-8 measures inspirational motivation (TL2); item 13-16 measures intellectual stimulation (TL3) and item 17-20 measures individualized consideration (TL1). The reliability was 0.965 , and the item-total correlation was between $0.522-0.852$.

Public service motivation (PSM) consisted of 5 items (PSM1-PSM5) adapted from Perry's (1996) five-item scale. The reliability was 0.849 , and the item-total correlation was between $0.612-0.748$.

Task performance $(T P)$ consisted of 11 items: social support $(\mathrm{TP} 1=4$ items), information provision $(\mathrm{TP} 2=4$ items), and technical care (TP3 $=3$ items) that was developed based on Greenslade (2008). The reliability was 0.815 , and the item-total correlation was between $0.587-0.768$.

Contextual performance $(C P)$ consisted of 14 items: job task support $(\mathrm{CP} 1=4$ items); interpersonal support $(\mathrm{CP} 2=5$ items); and organizational support $(\mathrm{CP} 3=5$ items) that was developed based on Greenslade (2008). The reliability was 0.833 , and the item-total correlation was between $0.678-0.705$.

Table 1. Characteristics of the nurses

\begin{tabular}{|c|c|c|}
\hline Characteristics & Frequency & Percent (\%) \\
\hline \multicolumn{3}{|l|}{ Gender $(n=800)$} \\
\hline Male & 41 & 5.1 \\
\hline Female & 759 & 94.9 \\
\hline \multicolumn{3}{|l|}{ Age (in years) $(n=803)$} \\
\hline 20 to 30 & 157 & 19.6 \\
\hline 31 to 40 & 349 & 43.5 \\
\hline 41 to 50 & 212 & 26.4 \\
\hline 51 to 60 & 85 & 10.6 \\
\hline \multicolumn{3}{|l|}{ Marital Status $(\mathrm{n}=780)$} \\
\hline Married & 507 & 62.4 \\
\hline Single & 247 & 30.4 \\
\hline Widowed, Separated & 26 & 3.2 \\
\hline \multicolumn{3}{|l|}{ Education $(n=753)$} \\
\hline Diploma & 9 & 1.2 \\
\hline Bachelor Degree & 679 & 92.6 \\
\hline Master Degree & 47 & 6.2 \\
\hline \multicolumn{3}{|l|}{ Years Work $(n=802)$} \\
\hline 10 or less than 10 & 341 & 42.5 \\
\hline 11 to 20 & 245 & 30.5 \\
\hline 21 to 30 & 216 & 26.9 \\
\hline \multicolumn{3}{|l|}{ Position $(\mathrm{n}=813$ ) } \\
\hline Registered Nurse & 794 & 99.0 \\
\hline Technical Nurse & 8 & 1.0 \\
\hline \multicolumn{3}{|l|}{ Type of Hospital $(n=813)$} \\
\hline Community Hospital & 392 & 48.2 \\
\hline general hospital & 319 & 39.3 \\
\hline regional hospital & 102 & 12.5 \\
\hline \multicolumn{3}{|l|}{ Province $(n=813)$} \\
\hline Yala & 217 & 26.7 \\
\hline Pattani & 267 & 32.8 \\
\hline Narathiwat & 329 & 40.5 \\
\hline
\end{tabular}

\subsection{Data Analysis}

This study involving empirical analysis examined causal relationships between variables, particularly between multiple independent and dependent variables. Structural Equation Modeling (SEM) with LISREL Software Version 8.72 was used in the following analyses where maximum likelihood (ML), which is a widely-used 
method for structural equation model analysis, was employed in estimating parameters of the models. As SEM, a multivariate statistical approach, is the most suitable analytical strategy (Byrne, 2010; Hair et al., 2010), it is usually used, by testing the relationships among multiple independent and dependent constructs, to explore the measurement and structural components of a model. However, this present study used Anderson and Gerbing's (1988) two-step procedure which comprises estimation of: first, the measurement model, and then the proposed structural model. First, the validity and reliability of the study variables were examined via confirmatory factor analyses (CFAs). Second, the hypotheses were examined via a structural equation model. To assess the model fits which include the overall model's chi-square, several indices were used, and the normed fit chi-square must not be over $5\left(\chi^{2 / \mathrm{df}<5)}\right.$ (Schumacker \& Lomax, 2004); the indices were the comparative fit index (CFI), the Tucker-Lewis Index (TLI), and the root mean square error of approximation (RMSEA). To indicate a good fit, CFI and TLI should be above 0.90 (Hu \& Bentler, 1999); and RMSEA should be between 0.05 and 0.08 (MacCallum, Browne, \& Sugawara, 1996).

\section{Results}

\subsection{The Measurement Model}

As shown in Table 2 and Figure 2, confirmatory factor analysis (CFA) was performed for the overall measurement model. It was found that in the model all the latent constructs were interrelated with each other. The results of the confirmatory factor analysis (CFA) showed that all the standardized factor loadings were more than 0.60 . The $t$-values were all significant at $\mathrm{p}<0.001$. Additionally, the overall measurement model was well-fitted to the data $(\chi 2 / \mathrm{df}=2.076, \mathrm{CFI}=0.978, \mathrm{GFI}=0.953, \mathrm{TLI}=0.973$, and RMSEA $=0.040)$. Consistent with the CFA results, it was found that the bivariate correlations among these key variables fall within an acceptable range $(\mathrm{r}<.70)$ (see Table 3 ).

In this study, significant factor loadings on each construct, which were statistically significant, were examined to establish convergent validity of which, according to Hair et al., 2010, 0.5 or higher is recommended for standardized loading estimates. Assessing convergent validity was conducted by examining the average variance extracted (AVE) from the measures. If the average variance extracted is 0.5 or over, then convergent validity is adequate (Hair et al., 2010). As shown in Table 4, all the factor loadings were above the recommended .50 value, ranging from .62 to .96 . Furthermore, it was found that the average variance extracted (AVE) ranged from .58-.71, which exceeded the recommended value of .50. In order to assess the discriminant validity of the constructs, the square roots of the average variance extracted (AVE) was employed (Fornell \& Larcker, 1981). It is recommended that these values should be higher than the correlations that are shared, in the model, between the construct and other constructs. As shown in Table 3, the square roots of the AVE are greater than the off-diagonal elements.

The square root of the average variance extracted AVE of each construct, which recommended by Hair et al., 2010, to exceed the correlation estimate between that construct and all other constructs, was compared with the correlation estimates between constructs in order to assess divergent validity. Table 3 shows comparison between the square root of the AVE and the inter-construct correlations for all constructs.

To assess the reliability of the study, the composite reliability (CR) was employed; to the CR a set of indicators share in their measurement of a construct (Koufteros, 1999), and Cronbach's alpha. It is a measure of the homogeneity and internal consistency of the items comprising a scale. Constructs with highly inter-correlated indicators are highly reliable. Therefore, they show they are measuring the same latent construct. Composite reliabilities (CR) of constructs also ranged from .79 to .87 , exceeding the recommended value of .60 (Bagozzi \& Yi, 1988). Furthermore, Cronbach's alphas showed satisfactory levels of internal consistency, ranging from .82 to .96 (Nunnally, 1978).

When a construct is different from other constructs, it means discriminant validity (Hair et al., 2010), and to assess discriminant validity of the construct, the square root of the average variance extracted (AVE) values is compared with the inter-construct correlations for all constructs in the model (Fornell \& Larcker, 1981). According to Hair et al., 2010, the square root of the average variance extracted (AVE) for each construct should be higher than the correlation estimate between that construct and all other constructs. As shown in Table 3, the square roots of the AVE are higher than the off-diagonal elements. Thus, it was concluded that the constructs are distinct.

Table 2. Factor Loadings, AVE, CR, and Cronbach's Alpha

\begin{tabular}{ccccccc}
\hline Construct & Items & Std. Factor Loading & t-value & CR & AVE & Cronbach's Alpha \\
\hline Public service motivation & PSM1 & 0.81 & $\ldots \ldots{ }^{*}$ & 0.87 & 0.58 & 0.85 \\
\hline
\end{tabular}




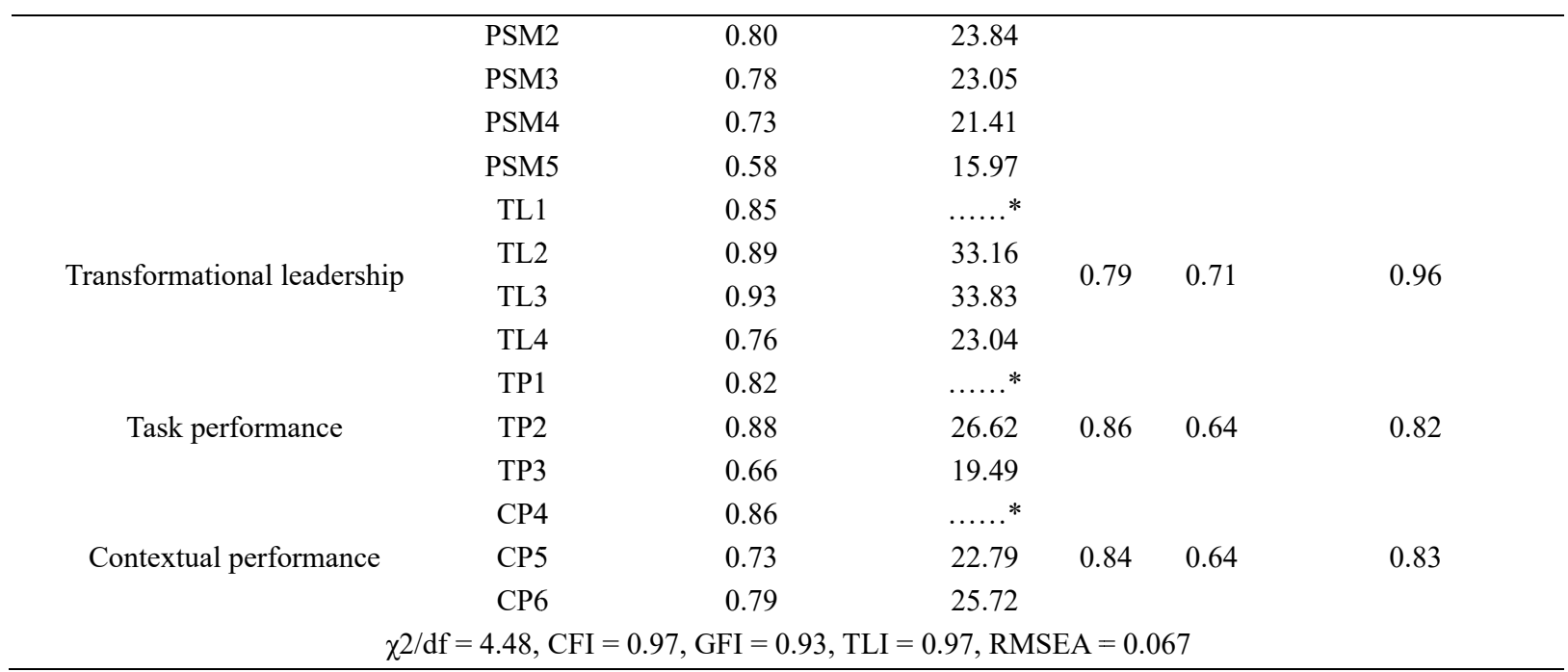

Note: * fixed parameter

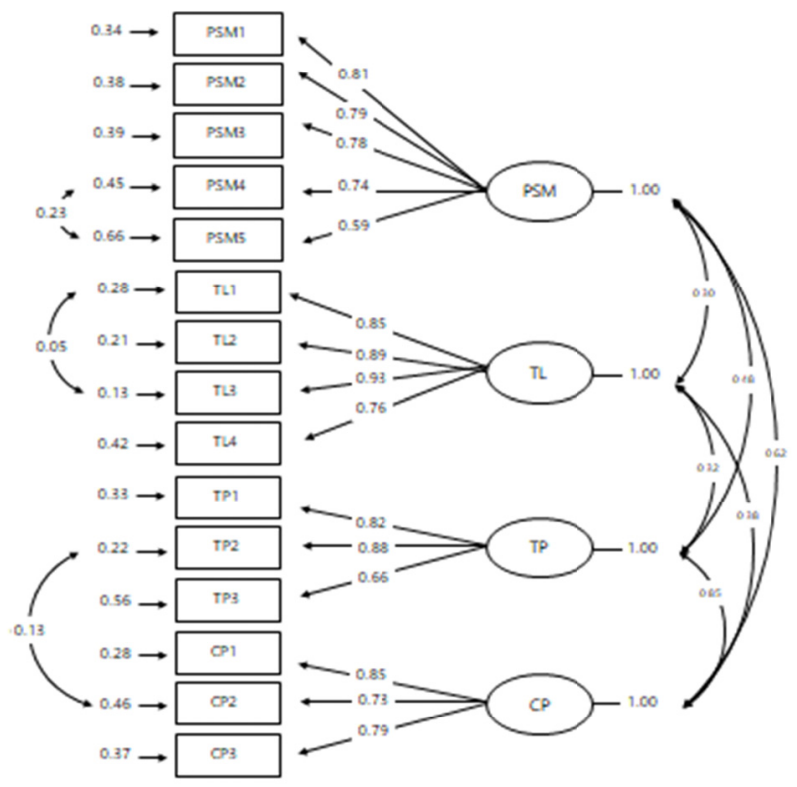

Figure 2. CFA Results for the Overall Measurement Model

Table 3. Means, Standard Deviations, Inter-Construct Correlations, and the Square Root of AVE

\begin{tabular}{|c|c|c|c|c|c|c|}
\hline variables & Mean & $S D$ & 1 & 2 & 3 & 4 \\
\hline 1.Public service motivation & 4.02 & .57 & $(0.84)$ & & & \\
\hline 2. Transformational leadership & 3.65 & .63 & 0.33 & $(0.76)$ & & \\
\hline 3. Job performance & 6.06 & .69 & 0.39 & 0.278 & $(0.80)$ & \\
\hline 4. Contextual Performance & 5.59 & .81 & 0.53 & 0.369 & 0.686 & $(0.80)$ \\
\hline
\end{tabular}

Note: $* * \mathrm{p}<.01$; Diagonal entries (in bold) are the square root of AVE; sub-diagonal entries are the latent construct inter-correlations. 


\subsection{The Structural Model}

As the results found that all the measurement models support the requirements of reliability and validity, the hypothesized structural model was then examined the relationships between the constructs.

The results of structural model analysis showed that the hypothesized model was consistent with the empirical data with $\chi 2 / \mathrm{df}=4.42, \mathrm{CFI}=0.98, \mathrm{GFI}=0.94, \mathrm{TLI}=0.97$, and RMSEA $=0.067$. The results of the analyses of direct effects, indirect effects, and total effects of the structural model of causal relationships between transformational leadership, public service motivation, task performance, and contextual performance are detailed in Table 4.

Table 4 shows that transformational leadership had a positive direct effect on public service motivation $(\beta=0.34$, $\mathrm{p}<.001)$, task performance $(\beta=0.32, \mathrm{p}<.001)$, and contextual performance $(\beta=0.38, \mathrm{p}<.001)$. Public service motivation (PSM) had a positive direct effect on task performance $(\beta=0.42, p<.001)$ and contextual performance $(\beta=0.55, p<.001)$. When considering variables that had indirect effects on task performance and contextual performance, it was found that transformational leadership has an indirect effect on task performance through public service motivation $(\beta=0.14, \mathrm{p}<.001)$ and an indirect effect on contextual performance through public service motivation $(\beta=0.19, \mathrm{p}<.001)$. In this model, transformational leadership and public service motivation (PSM) explain 26 percent of the variance in task performance $\left(\mathrm{R}^{2}=0.26\right)$, and 42 percent of the variance in contextual performance $\left(\mathrm{R}^{2}=0.42\right)$. Moreover, transformational leadership also accounts for 11 percent of the variance in PSM $\left(\mathrm{R}^{2}=0.11\right)$.

These findings provide support for all hypotheses, and the results of the structural equation model analysis are illustrated in Figure 2.

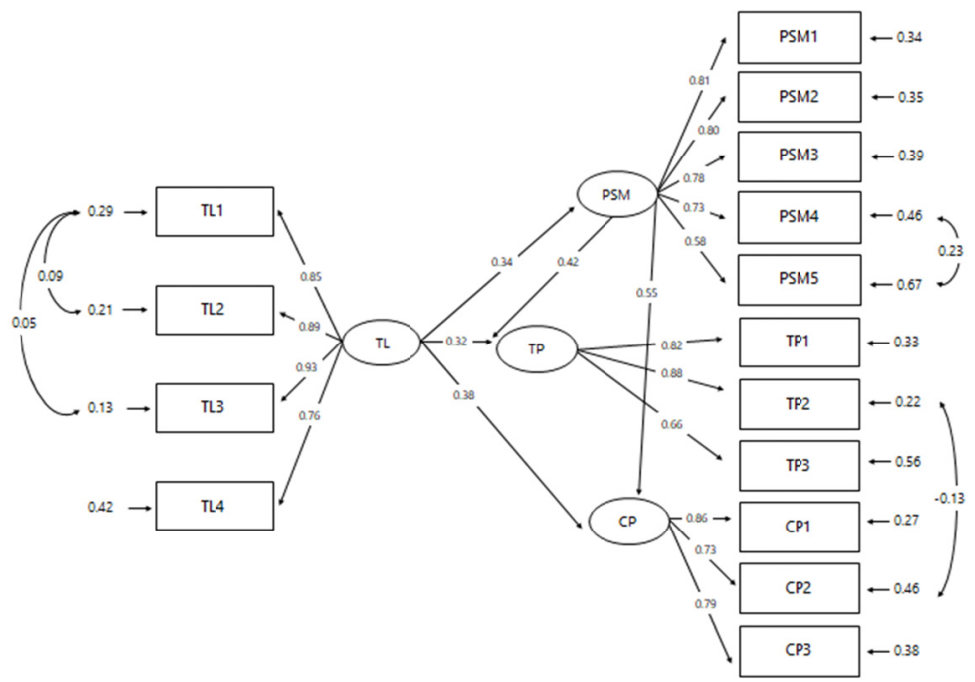

Figure 2. Structural Equation Model Results

Table 4. Direct effect, indirect effect, and total effect of the structural model (standardized estimates)

\begin{tabular}{|c|c|c|c|c|}
\hline \multirow{2}{*}{ Paths from } & \multirow{2}{*}{ to } & \multicolumn{3}{|c|}{ Path coefficient } \\
\hline & & Direct Effects & Indirect effects & Total effects \\
\hline Transformational leadership & \multirow{2}{*}{ Task performance } & $0.32 * * *$ & $0.14 * * *$ & $0.46^{* * *}$ \\
\hline Public service motivation & & $0.42 * * *$ & - & $0.42 * * *$ \\
\hline Transformational leadership & \multirow{2}{*}{ Contextual performance } & $0.38 * * *$ & $0.19 * * *$ & $0.57 * * *$ \\
\hline Public service motivation & & $0.55 * * *$ & - & $0.55^{* * *}$ \\
\hline Transformational leadership & Public service motivation & $0.34 * * *$ & - & $0.34^{* * *}$ \\
\hline
\end{tabular}

Note: $* * * \mathrm{p}<.001$

\section{Discussion and Conclusion}

The present study asked whether transformational leaders could influence nurses' job performance and if so, how? 
The results showed that transformational leadership was positively correlated with both task and contextual performance. These findings correspond to with results found by recent studies (Boerner, Eisenbeiss, \& Griesser, 2007; Judge \& Piccolo, 2004; Piccolo \& Colquitt, 2006).

Furthermore, it was found that PSM was one of the important mediators in the association between transformational leadership and task performance. This suggests that transformational leaders can help enhance motivation among nurses and create opportunities for them to utilize their skills in their organization in order to serve their patients. The finding and the assumptions of SDT are in congruence, which indicates that when the basic psychological needs are fulfilled, employees' autonomous motivation can be cultivated. This finding also provides support recent research (Paarlberg \& Lavigna, 2010; Park \& Rainey, 2008; Piccolo \& Colquitt, 2006; Ritz, 2009), which found that intrinsic motivation plays a very important role in explaining the virtuous influence of transformational leaders.

The results of the present study have several important implications for public hospitals and their managers. In particular, organizations should make efforts to develop transformational qualities in their managers who play a crucial role in translating organizational policy into practice. In so doing, the managers will become more equipped with specific tools that will motivate their employees to accept change in values which can help increase work effectiveness to an extent beyond that expected by the organization. Specifically, managers can do this by regularly communicating and reinforcing the desired organizational values to nurses under their supervision through group meetings and giving informal feedback. Supervisors may do this by setting work objectives for nurses and allow them to freely decide how to reach these adjectives and including them in the decision-making process. The findings of the present research also suggest that managers should try to be good role models and to give encouragement and motivation to their employees so that they could become more interested and enthusiastic in doing work that affects the lives of their patients. At the same time, it is important to pay attention to their employees' individuality and also support to improve their potential.

Although the current findings provide contribution to the leadership literature, there are several limitations that future research should take into account. First, the data were collected from a single source (i.e., nurses), which may raise concerns about common source bias. Future research should try to collected data from multiple sources. Secondly, it is likely that the nurses are nested within work units in each hospital and thus multilevel modeling could provide a more nuanced understanding of the influence of nurses' leaders. Thirdly, there could be other plausible explanation for the influence of leadership including in the nursing context including social learning and social exchange. Future research will benefit from examining a brooder set of mediators. Finally, it should be acknowledged that the hospitals are located in the Deep South of Thailand, which has long been affected by the unrest and uncertainty, which may have amplified the influence of leadership in this region. Future research will need to replicate the current findings in a different sample and context.

\section{References}

Alliance for Health Reform (2007). Rewarding quality performance: The role of nursing. Retrieved September, 13, from http://www.rwjf.org/files/publications/other/rewardingqualitynursing.pdf

Anderson, J. C., \& Gerbing, D. D. (1988). Structural equation modelling in practice: A review and recommended two-step approach. Psychological Bulletin, 103(3), 411-423. https://doi.org/10.1037/0033-2909.103.3.411

Avolio, B. J. (1999). Full leadership development: Building the vital forces in organizations. London: Sage Publications.

Bagozzi, R. P., \& Yi, Y. (1988). On the evaluation of structural equation models. Journal of the Academy of Marketing Science, 16(1), 74-94. https://doi.org/10.1007/BF02723327

Bass, B. M. (1985). Leadership and performance beyond expectations. New York, NY: Free Press.

Bass, B .M., \& Avolio, B .J) .1995.(MLQ Multifactor Leadership Questionnaire :Technical Report .Redwood City, CA :Mindgarden. https://doi.org/10.1037/t03624-000

Bass, B. M., \& Riggio, R. E. (2006). Transformational leadership (2nd ed.). Mahwah, NJ: Lawrence Erlbaum Associates.

Bernardin, H. J., \& Beatty, R. W. (1984). Performance appraisal: Assessing human behavior at work. Boston: Kent.

Boerner, S., Eisenbesiss, S. A., \& Griesser, D. (2007). Follower behavior and organizational performance: The impact of transformational leaders. Journal of Leadership and Organizational Studies, 13(3), 15-26. https://doi.org/10.1177/10717919070130030201 
Bono, J. E., \& Judge, T. A. (2003). Self-concordance at work: Toward understanding the motivational effects of transformational leaders. Academy of Management Journal, 46, 554-571. https://doi.org/10.2307/30040649

Borman, W. C., \& Motowidlo, S. J. (1993). Expanding the criterion domain to include elements of contextual performance. In N. Schmitt, \& W. C. Borman (Eds.), Personnel selection in organizations (pp. 71-98). San Francisco: Jossey-Bass.

Brewer, G. (2008). Employee and Organizational Performance. In J. L. Perry \& A. Hondeghem (Eds.), Motivation in Public Management: The Call of Public Service (pp. 136-156). Oxford: Oxford University Press.

Brewer, G., \& Selden, S. (1998). Whistle blowers in the Federal Civil Service: New evidence of the public service ethic. Journal of Public Administration Research and Theory, 8(3), 413-439. https://doi.org/10.1093/oxfordjournals.jpart.a024390

Burns, J. M. (1978). Leadership. New York, NY: Harper \& Row.

Byrne, B. M. (2010). Structural equation modeling with AMOS: Basic concepts, applications, and programming (2nd ed.). New York: Routledge Academy.

Campbell, J. P. (1990). Modeling the performance prediction Problem in industrial and organizational psychology. In M. D. Dunnette \& L. M. Hough (Eds.), Handbook of industrial and organizational psychology (2nd ed.). Palo Alto, Chicago: Consulting Psychologists Press.

Cerase, F. P., \& Farinella, D. (2009). Public service motivation: How does it relate to management reforms and changes in the working situation of public organizations? A case study of the Italian revenue agency. Public Policy and Administration, 24(3), 281-308. https://doi.org/10.1177\%2F0952076709103812

Downs, A. (1967). Inside Bureaucracy. New York: Harper Row. https://doi.org/10.7249/CB156

Fornell, C., \& Larcker, D. F. (1981). Structural equation models with unobservable variables and measurement error: Algebra and statistics. Journal of Marketing research, 18(3), 382-388. https://doi.org/10.1177/002224378101800313

Fuller, J. B., Patterson, C. E. P., Hester, K., \& Stringer, D. Y. (1996). A quantitative review of research on charismatic leadership. Psychological Reports, 78(1), 271-287. https://doi.org/10.2466/pr0.1996.78.1.271

Gagné, M., \& Deci, E. L. (2005). Self-determination theory and work motivation. Journal of Organizational Behavior, 26(4), 331-362. https://doi.org/10.1002/job.322

Greenslade, J. H. (2008). The organisational factors impacting on patient satisfaction: An examination of service climate, effort, and performance (Unpublished doctoral thesis). School of Psychology, University of Queensland, Australia.

Grant, A. M. (2007). Relational job design and the motivation to make a pro-social difference. Academy of Management Review, 32, 393-417. https://psycnet.apa.org/doi/10.2307/20159308

Gould-Williams, J. S. (2003). The importance of HR practices and workplace trust in achieving superior performance: A study of public-sector organizations. International Journal of Human Resource Management, 14(1), 28-54. https://doi.org/10.1080/09585190210158501

Hair, J. F., Black, W. C., Babin, B. J., \& Anderson, R. E. (2010). Multivariate data analysis: A global perspective (7th ed.). London: Pearson.

Hinkin, T. R., \& Schriesheim, C. A. (2008). A theoretical and empirical examination of the transactional and nonleadership dimensions of the Multifactor Leadership Questionnaire (MLQ). The Leadership Quarterly, 19(5), 501-513.

Hondeghem, A., \& Perry J. L. (2009). EGPA symposium on public service motivation and performance: Introduction. International Review of Administrative Sciences, 75(1), 5-9.

Houston, D. J. (2006). "Walking the Walk" of Public Service Motivation: Public Employees and Charitable Gifts of Time, Blood, and Money. Journal of Public Administration Research and Theory, 16(1), 67-86.

Hu, L., \& Bentler, P. (1999). Cutoff criteria for fit indexes in covariance structure analysis: Conventional criteria $\begin{array}{llllll}\text { versus new alternatives. Structural Equation } & \text { Modeling, }\end{array}$ https://doi.org/10.1080/10705519909540118

Kark, R., Shamir, B., \& Chen, G. (2003). The two faces of transformational leadership: Empowerment and dependency. Journal of Applied Psychology, 88, 246-255. https://doi.org/12731708 
Judge, T., \& Piccolo, R. (2004). Transformational and Transactional Leadership: A Meta-Analytic Test of Their Relative Validity. Journal of Applied Psychology, 5, 755-768.

Jung, D., \& Avolio, B. (2000). Opening the black box: An experimental investigation of the mediating effects of trust and value congruence on transformational and transactional leadership. Journal of Organizational Behavior, 21, 949-964.

Kelman, S. (1987). Making Public Policy: A Hopeful View of American Government. New York: Basic Books.

Kim, S. (2005). Individual-level factors and organizational performance in government organizations. Journal of Public Administration Research and Theory, 15(2), 245-261.

Kim, S. (2012). Does person-organization fit matter in the public sector? Testing the mediating effect of person-organization fit in the relationship between public service motivation and work attitudes. Public Administration Review, 72(6), 830-840. https://doi.org/10.1111/j.1540-6210.2012.02572

Kjeldsen, A. M., \& Jacobsen, C. B. (2013). Public service motivation and employment sector: Attraction or socialization? Journal of Public Administration Research and Theory, 23(4), 899-926.

Koufteros, X. A. (1999). Testing a model of pull production: A paradigm for manufacturing research using structural equation modeling. Journal of Operations Management, 17(4), 467-488.

MacCallum, R. C., Browne, M. W., \& Sugawara, H. M. (1996). Power analysis and determination of sample size for covariance structure modeling. Psychological Methods, 1(2), 130-149.

Naff, K. C., \& Crum, J. (1999). Working for America: Does public service motivation make a difference? Review of Public Personnel Administration, 19(4). https://doi.org/10.1177/0275074008317248

Leisink, P., \& Steijn, B. (2009). Public service motivation and job performance of public sector employees in the Netherlands. International Review of Administrative Sciences, 75(1), 35-52.

Lowe, K. B., Kroeck, K. G., \& Sivasubramaniam, N. (1996). Effectiveness correlates of transformational and transactional leadership: A meta-analytic review of the MLQ literature. Leadership Quarterly, 1(7), 385-42.

Motowidlo, S. J., Borman, W. C., \& Schmit, M. J. (1997). A theory of individual differences in task and contextual performance. Human Performance, 10, 71-83.

Moynihan, D. P., \& Pandey, S. K. (2007). The role of organizations in fostering public service motivation. Public Administration Review, 67(1), 40-53. https://doi.org/10.1111/j.1540-6210.2006.00695

Nunnally, J. C. (1978). Psychometric methods. NY: McGraw-Hill.

Paarlberg, L. E., \& Lavigna, B. (2010). Transformational leadership and public service motivation: Driving individual and organizational performance. Public Administration Review, 70(5), 710-718.

Park, S. M., \& Rainey, H. G. (2007). Antecedents, mediators, and consequences of affective, normative, and continuance commitment: Empirical tests of commitment effects in federal agencies. Review of Public Personnel Administration, 27(3), 197-226. https://doi.org/10.1177\%2F0734371X06296866

Park, S. M., \& Rainey, H. G. (2008). Leadership and public service motivation in U.S. federal agencies. International Public Management Journal, 11(1), 109-142.

Perry, J. L. (1996). Measuring public service motivation: An assessment of construct reliability and validity. Journal of Public Administration Research and Theory, 6(1), 5-23. https://doi.org/10.1093/oxfordjournals.jpart.a024303

Perry, J. L. (2000). Bringing society in: Toward a theory of public-service motivation. Journal of Public Administration Research and Theory, 10(2), 471-488.

Perry, J. L., \& Vandenabeele, W. (2008). Behavioral dynamics: Institutions, identities, and self-regulation. In J. Perry \& A. Hondeghem (Eds.), Motivation in public management: The call of public service (pp. 56-79). Oxford: Oxford University Press.

Perry, J. L., \& Wise, L. R. (1990). The motivational bases of public service. Public Administration Review, 50(3), 367-373. https://doi.org/10.1080/23276665.2014.892272

Piccolo, R. F., \& Colquitt, J. A. (2006). Transformational Leadership and Job Behaviors: The Mediating Role of Core Job Characteristics. Academy of Management Journal, 49, 327-340.

Pillai, R., Schreisheim, C. A., \& Williams, E. A. (1999). Airness perceptions and trust as mediators for transformational leadership and transactional leadership: A two-sample study. Journal of Management, 25, 
897-933. https://doi.org/10.1177\%2F014920639902500606

Podsakoff, P. M., MacKenzie, S. B., Moorman, R. H., \& Fetter, R. (1990). Transformational leader behaviors and their effects on followers' trust in leader, satisfaction, and organizational citizenship behaviors. Leadership Quarterly, 1, 107-142.

Ritz, A. (2009). Public service motivation and organizational performance in Swiss federal government. International Review of Administrative Sciences, 75(1), 153-178.

Schumacker, R., \& Lomax, R. (2004). A Beginner's Guide to Structural Equation Modeling (2nd ed.). Mahwah, NJ: Lawrence Erlbaum.

Smith, C. A., Organ, D. W., \& Near, J. P. (1983). Organizational citizenship behavior: Its nature and antecedents. Journal of Applied Psychology, 68(4), 653-663.

Sosik, J. J., Avolio, B. J., \& Kahai, S. S. (1997). Effects of leadership style and anonymity on group potency and effectiveness in a group decision support system environment. Journal of Applied Psychology, 82, 89-103.

Taylor, J. (2008). Organizational influences, public service motivation and work outcomes: An Australian study. International Public Management Journal, 11(1), 67- 88.

Taylor, J., \& Westover, J. H. (2011). Job satisfaction in the public service: The effects of public service motivation, workplace attributes and work relations. Public Management Review, 13(5), 731-751.

Tejeda, M. J., Scandura, T. A., \& Pillai, R. (2001). The MLQ revisited: Psychometric properties and recommendations. The Leadership Quarterly, 12, 31-52.

Trottier, T., Van Wart, M., \& Wang, X. (2008). Examining the Nature and Significance of Leadership in Government Organizations. Public Administration Review, 68(2), 319-333.

Vandenabeele, W. (2007). Toward a public administration theory of public service motivation: An institutional approach. Public Management Review, 9(4), 545-556. https://doi.org/10.1080/14719030701726697

Vandenabeele, W. (2009). The mediating effect of job satisfaction and organizational commitment on self-reported performance: More robust evidence of the PSM-performance relationship. International Review of Administrative Sciences, 75(1), 11-34. https://doi.org/10.1177\%2F0020852308099504

Wright, B. E., Moynihan, D. P., \& Pandey, S. K. (2012). Pulling the Levers: Transformational Leadership, Public Service Motivation, and Mission Valence. Public Administration Review, 72, 206-215.

Wright, B. E., \& Pandey, S. K. (2010). Transformational Leadership in the Public Sector: Does Structure Matter? Journal of Public Administration Research and Theory, 20(1), 75-89. https://www.jstor.org/stable/41433294

Xiaohua, L. (2008). An empirical study on public service motivation and the performance of government employee in China. Canadian Social Science, 4(2), 18-28. https://doi.org/1923669720080402.003/348

\section{Copyrights}

Copyright for this article is retained by the author(s), with first publication rights granted to the journal.

This is an open-access article distributed under the terms and conditions of the Creative Commons Attribution license (http://creativecommons.org/licenses/by/4.0/). 